\title{
Adhesion of Real Seal to Human Root Dentin Treated with Different Solutions
}

\author{
Renata BALDISSERA ${ }^{1}$ \\ Ricardo Abreu da ROSA ${ }^{1}$ \\ Márcia Helena WAGNER ${ }^{1}$ \\ Milton Carlos KUGA ${ }^{2}$ \\ Fabiana Soares GRECCA ${ }^{1}$ \\ Augusto BODANEZI ${ }^{1}$ \\ Luis Carlos da Fontoura FRASCA ${ }^{1}$ \\ Marcus Vinícius Reis SÓ ${ }^{1}$ \\ ${ }^{1}$ Department of Conservative Dentistry, Dental School, \\ UFRGS - Federal University of Rio Grande do Sul, Porto Alegre, RS, Brazil. \\ ${ }^{2}$ Department of Restorative Dentistry, Araraquara Dental School, \\ UNESP - Univ Estadual Paulista, Araraquara, SP, Brazil
}

\begin{abstract}
The aim of this study was to evaluate the effects of different irrigants on sealer-dentin bond strength when using Real Seal. Thirty single-rooted teeth were divided into 3 groups. In one group, the teeth were irrigated with $3 \mathrm{~mL}$ of $2.5 \% \mathrm{NaOCl}$ after each file change, flushed with $17 \%$ EDTA for $3 \mathrm{~min}$ and finally rinsed with $3 \mathrm{~mL}$ of $2.5 \% \mathrm{NaOCl}$. In the other two groups, rinse with $\mathrm{NaOCl}$ was replaced with $2 \%$ chlorhexidine gluconate (CHX) and $0.9 \%$ saline, respectively. Each root was sectioned transversally into apical, middle and coronal thirds to obtain 2-mm-thick slices. Each slice was filled with Real Seal and Resilon. Push-out test was used to analyze bond strength and failure modes were classified as adhesive, cohesive or mixed, according to SEM observations. The push-out test did not reveal any statistically significant difference $(p>0.05)$ between the irrigants. However, the groups exhibited significantly different $(\mathrm{p}<0.05)$ bond strengths in terms of the root canal third. Higher bond strength was observed at the apical third when compared with coronal third, while middle third presented intermediary values. Fifteen specimens were analyzed by SEM (5 per group). Eleven specimens exhibited adhesive failures ( 5 in saline, 4 in $\mathrm{NaOCl}$ and 2 in $\mathrm{CHX}$ group); 2 cohesive failures were observed in the CHX group, and 1 mixed failure each was observed in the $\mathrm{CHX}$ and $\mathrm{NaOCl}$ groups. The tested irrigants did not influence the bond strength of Resilon and Real Seal to dentin. The apical third exhibited higher mean bond strengths and adhesive failures were predominant.
\end{abstract}

Key Words: Endodontics, endodontic sealer, irrigation protocol, bond strength.

\section{INTRODUCTION}

Successful endodontic therapy depends on thorough chemomechanical preparation of the root canal system as well as three-dimensional filling that provides complete sealing of the spaces previously occupied by the canal contents (1). Improvements in adhesive technology directed their attention toward the characteristics of the filling material, for decreasing marginal, apical and coronal infiltration, and increasing the adhesion of the endodontic sealer to root canal walls (2). Adhesion can be defined as the process in which two surfaces of different molecular compositions are joined by chemical, physical or mechanical forces (3). The adhesion between dental structures and resin-based sealers is the result of a physicochemical interaction across the interface, enabling the union between the filling material and root canal walls (3).

Recently, methacrylate resin-based sealers such as Epiphany (Pentron Clinical Technologies, Wallingford, CT, USA), Real Seal (SybronEndo, Orange, CA, USA), and Endo-REZ (Ulradent Products Inc., South Jordan, UT, USA) associated with Resilon cones (Resilon Research, Madison, CT, USA) were introduced to

Correspondence: Ricardo Abreu da Rosa, Rua Gomes Carneiro 408, Dores, 97050-470 Santa Maria RS, Brasil. Tel: +55-55-3221-5593. e-mail: rabreudarosa@yahoo.com.br 
replace gutta-percha and conventional sealers (4). These systems interact chemically with dentin and form a resin monoblock that adheres to the walls of the root canals by the formation of intratubular tags (4). Some researchers suggest that the monoblock effect is suitable for promoting optimal root canal sealing and minimizing coronal leakage (5).

Several irrigating solutions are used in the chemomechanical preparations to promote disinfection, dissolve pulp tissue and remove the smear layer. However, no available irrigant can act simultaneously on organic and inorganic compounds of the smear layer (6). $\mathrm{NaOCl}$ exhibits pulp dissolution capacity, antimicrobial action and neutralization of toxic products of the root canal (7). Chlorhexidine gluconate ( $\mathrm{CHX})$ is a biocompatible solution that could replace $\mathrm{NaOCl}$ as an irrigating solution. $\mathrm{CHX}$ has bactericidal properties because of its ability to precipitate and coagulate bacterial intracellular constituents (8). Furthermore, its antibacterial action persists in root canals for 12 weeks after its initial use as an endodontic irrigant $(8,9)$.

The use of $17 \%$ ethylenediaminetetraacetic acid (EDTA) promotes smear layer removal prior to canal filling, allows better adaptation of the sealer to root dentin (10) and exhibits excellent root canal sealing (10). Moreover, the sequence and the type of final irrigant may affect the bond strength of endodontic sealers (11-13).

The purpose of this study was to evaluate the effect of different irrigants on sealer-dentin bond strength when using a methacrylate resin-based sealer (Real Seal) and Resilon cones. The failure modes were analyzed by scanning electron microscopy (SEM) and classified as adhesive, cohesive or mixed.

\section{MATERIAL AND METHODS}

This study was submitted to and approved by the Ethics Committee of the Federal University of Rio Grande do Sul, Brazil. Thirty single-rooted human teeth (maxillary incisors and mandibular premolars) were used in this study. Only teeth without any external crack, calcification or previous endodontic treatment were included in this study.

The teeth were stored in $0.9 \%$ saline solution at $4^{\circ} \mathrm{C}$ until use. The coronal portions were sectioned with a diamond disc and machine cut (ExtecLabcut 1010; Enfield, CT, USA) under water cooling at the cementenamel junction. The working lengths were established by subtracting $1 \mathrm{~mm}$ from the length recorded when the tips of \#15 K-files (DentsplyMaillefer, Ballaigues, Switzerland) were visible at the apical foramina. The root canals were prepared using manual technique until \#80 K-file was used. At the chemomechanical preparation phase, teeth were divided into the following 3 experimental groups. In one group, the teeth were irrigated with $3 \mathrm{~mL}$ of $2.5 \% \mathrm{NaOCl}$ after each file change, flushed with 17\% EDTA for $3 \mathrm{~min}$ and finally rinsed with $3 \mathrm{~mL}$ of $2.5 \% \mathrm{NaOCl}$. In the other two groups, the teeth were irrigated using $2 \% \mathrm{CHX}$ and $0.9 \%$ saline instead of $\mathrm{NaOCl}$.

The roots were sectioned transversally with a diamond disc using a cutting machine under water cooling and three 2-mm-thick slices were obtained, 1 for each root third (i.e., apical, middle and coronal). After labeling the specimens according to the root third and irrigation protocol, they were ultrasonically cleaned for 2 min with distilled water.

Dentin treatment and Real Seal mixing were conducted according to the manufacturer's instructions. Next, the slices were filled using a cold lateral compaction technique. The excess gutta-percha in the coronal and apical portion of the slice was removed with a flame-heated plugger. Light curing was performed at the coronal side of the slice for $40 \mathrm{~s}$, at $5 \mathrm{~mm}$ from the specimens (XL 2500; 3M ESPE, St. Paul, MN, USA) and the specimens were kept in a humid environment at $37^{\circ} \mathrm{C}$ for 1 week.

The push-out test was performed in a universal testing machine (EMIC, São José dos Pinhais, PR, Brazil) at a crosshead speed of $1 \mathrm{~mm} / \mathrm{min}$. Each slice was positioned on a metallic device with a central opening $(\varnothing=3 \mathrm{~mm})$ larger than the canal diameter. The most coronal portion of the specimen was placed downward. For push-out testing, a metallic cylinder $\left(\varnothing_{\text {extremity }}=1.3\right.$ $\mathrm{mm}$ ) induced a load in an apical-to-coronal direction on the Resilon cone without applying any pressure to the sealer and/or dentin. The bond strength was determined using a computer software program connected to the universal testing machine. The maximum load applied to the filling material before debonding was recorded in newtons $(\mathrm{N})$. The bond strength $(\sigma)$ in MPa was calculated as F/A, where $\mathrm{F}$ is the load for filling rupture $(\mathrm{N})$ and $\mathrm{A}$ is the bonded area $\left(\mathrm{mm}^{2}\right)(14)$.

After push-out testing, the mean bond strength for each specimen was calculated. Two-way ANOVA was used for testing significant correlations between the irrigants and the root thirds. A Bonferroni post-hoc test was used for pair-wise comparisons among means 
when ANOVA results were significant. The significance level was set at $p<0.05$. Statistical analysis was done with SPSS 15.0 for Windows (SPSS Inc., Chicago, IL, USA).

Five specimens of each group were processed for SEM analysis of the sealer-dentin interface. The specimens were sputter-coated with palladium (MED 010; Balzers Union, Balzers, Liechtenstein) and analyzed with a scanning electron microscope (6060; Jeol Ltd., Tokyo, Japan) at $\times 80$ and $\times 150$ magnifications to classify the failure modes. Failures were considered adhesive if the sealer was totally separated from dentin (i.e., dentin surface without sealer), cohesive if the fracture occurred within the sealer (i.e., dentin surface totally covered by the sealer) and mixed when a mixture of adhesive and cohesive modes occurred (i.e., dentin surface partially covered by the sealer).

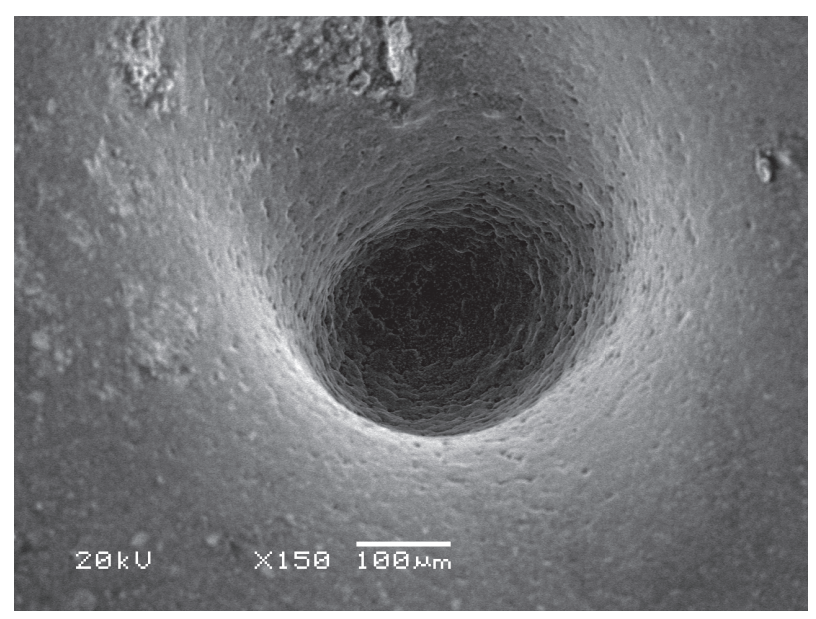

Figure 1. Adhesive failure in the $\mathrm{NaOCl}$ group.

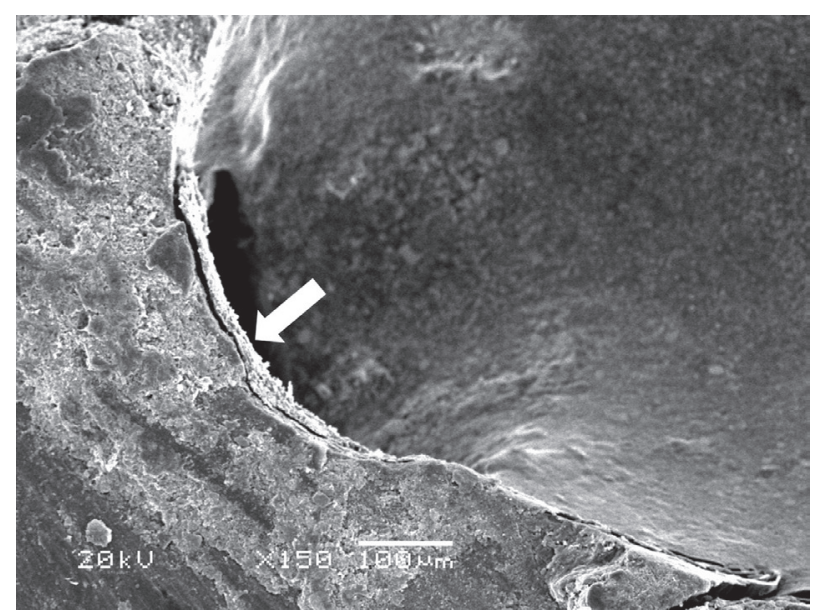

Figure 2. Mixed failure in the CHX group. Note the sealer attached to the root canal wall (arrow).

\section{RESULTS}

Table 1 presents the mean push-out bond strength values. The irrigants did not affect significantly $(p>0.05)$ the push-out bond strengths when the same root canal third was analyzed. However, statistically significant differences $(p<0.05)$ were found when the root canal thirds were compared. $\mathrm{CHX}, \mathrm{NaOCl}$ and Saline groups exhibited statistically significant differences $(\mathrm{p}<0.05)$ with respect to their coronal and apical thirds. The apical third presented a higher mean push-out bond strength regardless of the irrigation regimen.

In the Saline group, 5 adhesive failures were observed, whereas in the $\mathrm{NaOCl}$ group, 4 adhesive failures and 1 mixed failure occurred. In the CHX group, SEM analysis revealed the occurrence of 2 adhesive, 2 cohesive, and 1 mixed failure. Figures 1-3 present, respectively, adhesive failures in the $\mathrm{NaOCl}$ group, mixed failures in the CHX group and cohesive failures in the Saline group.

Table 1. Means and standard deviations of push-out bond strengths $(\mathrm{MPa})$.

\begin{tabular}{lccc}
\hline Final irrigant & Coronal & Middle & Apical \\
\hline $\mathrm{CHX}$ & $1.96(1.2)^{\mathrm{a}, \mathrm{A}}$ & $6.9(4.8)^{\mathrm{a}, \mathrm{b}, \mathrm{A}}$ & $13.2(7.5)^{\mathrm{b}, \mathrm{A}}$ \\
$\mathrm{NaOCl}$ & $1.0(0.8)^{\mathrm{a}, \mathrm{A}}$ & $10.4(8.5)^{\mathrm{a}, \mathrm{b}, \mathrm{A}}$ & $15.0(5.8)^{\mathrm{b}, \mathrm{A}}$ \\
Saline solution & $3.5(4,6)^{\mathrm{a}, \mathrm{A}}$ & $5.7(6.6)^{\mathrm{a}, \mathrm{b}, \mathrm{A}}$ & $16.3(7.64)^{\mathrm{b}, \mathrm{A}}$ \\
\hline
\end{tabular}

Same lowercase superscript letters in the rows and uppercase letters the in columns indicate no statistically significant difference $(\mathrm{p}>0.05)$.

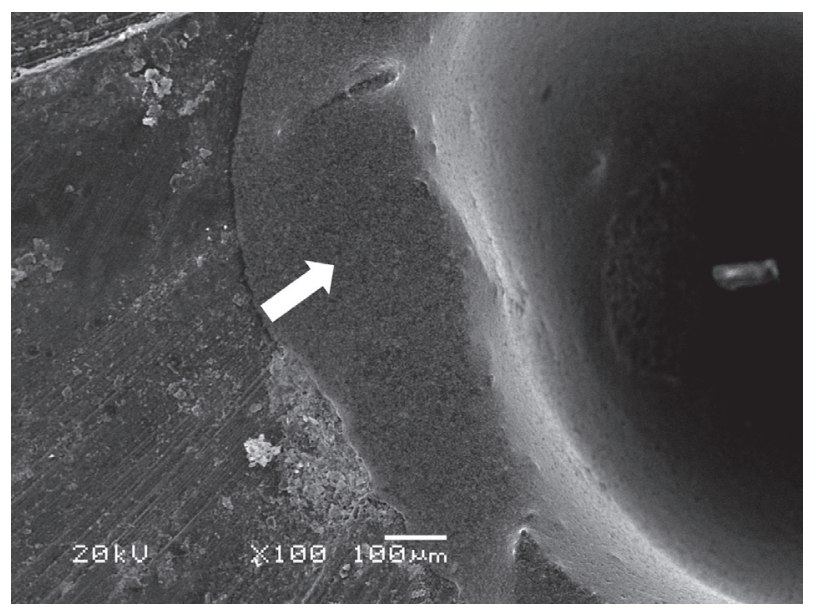

Figure 3. Cohesive failure in the Saline group. The arrow indicates the sealer layer. 


\section{DISCUSSION}

Adhesion between endodontic sealers and root canal dentin is important for the maintenance of filling integrity (11). Thus, the bond strength between dentin and endodontic sealers as well as their interface behavior after push-out tests are important.

Some factors may affect the push-out bond strength, including the method employed to quantify the bond strength (12) and treatment of the dentin surface $(13,15)$. Previous studies have investigated the effects of different irrigation regimens on the push-out bond strengths of methacrylate resin-based sealers $(5,11,16)$. However, the effects of CHX have not been reported.

The push-out test was performed because it provides smaller adhesive areas and thus more uniform stress distribution on the adhesive interface. Few specimens were lost during the experiment, low standard deviations were obtained and the procedure was easily performed (17). Some researchers have filled the root canals prior to the push-out slices $(5,15)$; they advocate the use of gutta-percha/Resilon and sealer insertion into the root canal because it simulates clinical conditions more closely. On the other hand, sectioning the root after filling could move the filling mass, which affects the bond strength values and even the failure modes (15). In the present study, slices were created and subsequently filled using cold lateral compaction technique. This protocol allows using smaller sealer amounts and the formation of fewer voids and gaps (18). Once the slice was filled, the excess gutta-percha was removed with a flame-heated plugger in the coronal and apical portion of the slice.

Since the aim of the study was to evaluate the influence of irrigants on the bond strength of a methacrylate resin-based sealer (Real Seal), previous filling may have been affected by other variables such as a high $\mathrm{C}$-factor (the ratio between bonded and nonbonded surfaces), polymerization shrinkage (19) and different light availability at the root canal thirds (17). The deleterious influence of these factors was observed when the present results were compared to those of recent investigations $(5,15)$. Babb et al. (20) found similar bond strength values using methods similar to those used in this study. This probably occurred because of a similar amount of available light during the light-curing procedures compared to light-curing of the coronal portion of the root canal. In this case, it is hard to provide light to the apical third; consequently, sealer and adhesive polymerization may be impaired even in dual-curing systems $(5,15)$. Light curing accelerates the conversion degree of monomers into polymers and the conversion degree depends on the amount of energy supplied to the monomers by light curing (21). Moreover, the high $\mathrm{C}$-factor in the root canals maximizes the polymerization shrinkage stress of adhesive systems (22).

There was no significant difference between the irrigation treatments in the same root canal third $(p<0.05)$. EDTA can act on tooth mineral matrix and promotes the removal of the smear layer formed during biomechanical preparation, which enables better penetration of sealers into the dentinal tubules, increasing the contact surface of the filling material with dentin (23). The chelating action of EDTA (an inorganic compound) in dentin may have overlapped with the effects of irrigation solutions. This is because, irrespective of the root canal third, the 3 irrigation regimens exhibited similar bond strengths. High bond strengths were found in this study (Table 1) even with the possible deleterious effect of EDTA on the push-out bond strengths of methacrylate resinbased sealers (24). EDTA decreases the wetting ability of dentin; therefore, a dentin surface unsuitable for the adhesion of hydrophilic methacrylate resin-based sealers might be provided $(11,24)$. On the other hand, when CHX is used, a surfactant in its composition increases the dentin surface energy and consequently its wettability - a property required for the adhesion of the Resilon/Real Seal system (11).

When the push-out bond strengths of each irrigation regimen were compared separately by root third, the mean values increased from the coronal to apical third. Statistically significant differences were found between the coronal and apical root third in all experimental groups $(p>0.05)$. Even though the apical portions had geometrical features favorable to dislodgment, these portions had higher push-out bond strengths. The bond strength $(\sigma)$ in MPa was calculated as $\mathrm{F} / \mathrm{A}$, where $\mathrm{F}$ is the load for specimen rupture $(\mathrm{N})$ and $\mathrm{A}$ is the bonded area $\left(\mathrm{mm}^{2}\right)$. To determine the bonded interface area, the following equation was used to calculate the lateral area of a circular straight cone section with parallel bases: $A=2 \pi g(R 1+R 2)$, where $\pi$ is 3.14 , $\mathrm{g}$ is slant height, $\mathrm{R} 1$ is the smaller base radius and $\mathrm{R} 2$ is the larger base radius. The following equation was used to determine the slant height: $g^{2}=\left(h^{2}+[R 2-R 1]^{2}\right)$, where $h$ is the section height. R1 and R2 were obtained by measuring the internal diameters of the smaller and larger bases, respectively, which corresponded to the 
internal diameter between the root canal walls (13). Thus, the slant height is inversely proportional to bond strength: the higher the section slant, the lower the resistance to dislodgment (13). Therefore, curiously the results indicate that slices from the coronal and middle thirds, which have geometrical features unfavorable to dislodgement had lower mean strengths than apical thirds, which have geometrical features favorable to dislodgement. In addition, these findings may also be associated with the root canal section at each level: the apical portion presents a circular root section, and coronal and middle portions may present oval, trapezoidalshaped or even flattened root canal sections. Variations in the root canal anatomy in the middle and coronal thirds lead to misfit of the main gutta-percha cone or even fiber posts (25). In both cases, thick sealer/cement layers impaired the bond strength (25). Therefore, the use of accessory cones is necessary to reduce the sealer layer at the middle and coronal thirds.

The main factor responsible for the difference of failure patterns between the CHX group and the other groups is the surfactant in its composition. The surfactant increases the surface energy of dentin and hence its wettability. In turn, this increases the flow and penetrability of hydrophilic sealers such as Real Seal. Higher penetrability into dentinal tubules influenced the failure patterns of the experimental groups, but did not influence the push-out bond strength.

In conclusion, different irrigants did not affect the Real Seal adhesiveness to root dentin. The bond strength values vary according to the root canal third. The highest values were observed at the apical third and adhesive failures were predominant in SEM analysis.

\section{RESUMO}

O objetivo deste estudo foi avaliar os efeitos de diferentes soluções irrigadoras na resistência adesiva do Real Seal à dentina radicular. Trinta dentes monorradiculares foram divididos em 3 grupos: Grupo 1 - os dentes foram irrigados com $3 \mathrm{~mL}$ de $\mathrm{NaOCl}$ $2,5 \%$ após cada troca de instrumento, irrigados com EDTA 17\% por 3 min e lavagem final com $\mathrm{NaOCl} 2,5 \%$. Nos Grupos 2 e 3 , o $\mathrm{NaOCl}$ foi substituído por digluconato de clorexidina $2 \%$ (CHX) e solução salina $0,9 \%$, respectivamente. Cada raiz foi seccionada transversalmente nos terços apical, médio e cervical para obter fatias de $2 \mathrm{~mm}$ de espessura. Cada slice foi obturado com Real Seal e Resilon. Teste de push-out foi usado para analisar a resistência adesiva e os padrões de falha foram classificados como adesiva, coesiva e mista de acordo com MEV. O teste de push-out não revelou diferença estatisticamente significante entre os irrigantes $(p<0,05)$. Porém, os grupos exibiram diferentes valores de resistência adesiva de acordo com o terço radicular
( $p>0,05)$. Maior resistência adesiva foi observada na região apical quando comparado com o terço cervical, enquanto que o terço médio apresentou valores intermediarios. Quinze espécimes foram analisados através de MEV (5 por grupo). Onze espécimes exibiram falhas adesivas ( 5 no grupo da solução salina, 4 no grupo $\mathrm{NaOCl}$ e 2 na CHX); duas falhas coesivas foram observadas no grupo CHX e uma falha mista foi observada no grupo da CHX e uma no $\mathrm{NaOCl}$. Os irrigantes testados não influenciaram a resistência adesiva do Resilon e do Real Seal à dentina radicular. O terço apical apresentou maior resistência adesiva e falhas adesivas foram predominantes para todos os grupos

\section{REFERENCES}

1. Cohen S, Burns RC. Pathways of the pulp. St Louis: Mosby; 1998.

2. Nakabayashi N, Pashley D. Hybridization of dental hard tissues. Tokyo: Quintessence Publishing Co.; 1998:130.

3. Kouvas V, Liolios E, Vassiliadis L, Parissis-Messimeris S, Boutsioukis A. Influence of smear layer on depth of penetration of three endodontic sealers: an SEM study. Endod Dent Traumatol 1998;14:191-195.

4. Sousa-Neto MD, Passarinho-Neto JG, Carvalho-Júnior JR, CruzFilho AM, Pécora JD, Saquy PC. Evaluation of the effect of EDTA, EGTA and CDTA on dentin adhesiveness and microleakage with different root canal sealers. Braz Dent J 2002;13:123-128.

5. Nunes VH, Silva RG, Alfredo E, Sousa-Neto MD, Silva-Sousa YTC. Adhesion of Epiphany and AH Plus sealers to human root dentin treated with different solutions. Braz Dent J 2008; 19:46-50.

6. Shipper G, Ørstavik D, Teixeira FB, Trope M. An evaluation of microbial leakage in roots filled with a thermoplastic synthetic polymer-based root canal filling material. J Endod 2004;30:342347.

7. Spanó JC, Barbin EL, Santos TC, Guimarães LF, Pécora JD. Solvent action of sodium hypochlorite on bovine pulp and physico-chemical properties of resulting liquid. Braz Dent J 2001;12:154-157.

8. Wang CS, Arnold RR, Trope M, Teixeira FB. Clinical efficiency of $2 \%$ chlorhexidine gel in reducing intracanal bacteria. J Endod 2007;33:1283-1289.

9. White RR, Hays GL, Janer LR. Residual antimicrobial activity after canal irrigation with chlorhexidine. J Endod 1997;23:229231.

10. McComb D, Smith DC, Beagrie GS. The results of "in vivo" endodontic chemomechanical instrumentation. A scanning electron microscopic study. J Br Endod Soc 1976;9:11-18.

11. Hashem AAR, Ghoneim AG, Lutfy RA, Fouda MY. The effect of different irrigating solutions on bond strength of two root canalfilling systems. J Endod 2009;35:537-540.

12. Cecchin D, Farina AP, Galafassi D, Barbizam JVB, Corona SAM, Carlini-Júnior B. Influence of sodium hypochlorite and EDTA on the microtensile bond strength of a self-etching adhesive system. J Appl Oral Sci 2010;18:385-389.

13. Gu X-H, Mao C-Y, Liang C, Wang H-M, Kern M. Does endodontic post space irrigation affect smear layer removal and bonding effectiveness? Eur J Oral Sci 2009;117:597-603.

14. Valandro LF, Galhano GA, Melo RM, Mallmann A, Scotti R, Bottino MA. Effect of mechanical cycling on the push-out bond strength of fiber posts adhesively bonded to human root dentin. Oper Dent 2007;32:579-588

15. Gesi A, Raffaelli O, Goracci C, Pashley DH, Tay FR, Ferrari M. Interfacial strength of Resilon and gutta-percha to intraradicular dentin. J Endod 2005;31:809-813. 
16. Shokouhinejad N, Sharifian MR, Jafari M, Sabeti MA. Push-out bond strength of Resilon/Epiphany self-etch and gutta-percha/ AH26 after different irrigation protocols. Oral Surg Oral Med Oral Pathol 2010;110:e88-e92.

17. Goracci C, Tavares AU, Fabianelli A, Monticelli F, Raffaelli O, Cardoso PC, Tay F, Ferrari M. The adhesion between fiber posts and root canal walls: comparison between microtensile and pushout bond strength measurements. Eur J Oral Sci 2004;112:353361.

18. Grandini S, Goracci C, Monticelli F, Borracchini A, Ferrari M. SEM evaluation of the cement layer thickness after luting two different posts. J Adhes Dent 2005;7:235-240.

19. Cavenago BC, Duarte MA, Ordinola-Zapata R, Marciano MA, Carpio-Perochena AE, Bramante CM. Interfacial adaptation of an epoxy-resin sealer and a self-etch sealer to root canal dentin using the System B or the single cone technique. Braz Dent J 2012;23:205-211.

20. Babb BR, Loushine RJ, Bryan TE, Ames JM, Causey MS, Kim J, et al.. Bonding of self-adhesive (self-etching) root canal sealers to radicular dentin. J Endod 2009;35:578:582.
21. Mendes LC, Tedesco AD, Miranda MS. Determination of degree of conversion as function of depth of a photo-initiated dental restoration composite. Polymer Testing 2005;24:418-422.

22. Tay FR, Loushine RJ, Weller RN, Kimbrough WF, Pashley DH, Mak YF, et al.. Ultrastructural evaluation of the apical seal in roots filled with a polycaprolactone-based root canal filling material. J Endod 2005;31:514-519.

23. Hülsmann M, Heckendorff M, Lennon A. Chelating agents in root canal treatment: mode of action and indications for their use. Int Endod J 2003;36:810-830.

24. Dogan Buzoglu H, Calt S, Gumusderelioglu M. Evaluation of the surface free energy on root canal dentine walls treated with chelating agents and $\mathrm{NaOCl}$. Int Endod J 2007;40:18-24.

25. Da Rosa RA, Bergoli CD, Kaizer OB, Valandro LF. Influence of cement thickness and mechanical cycling on the push out bond strength between posts and root dentin. Gen Dent 2011;59:e156-e161. 